Chapter 3

\title{
Translation, Nation Branding and Indo- chic: The Circulation and Reception of South Asian Canadian Fiction in Spain
}

\author{
Belén Martín-Lucas
}

Literary translation constitutes an important marker of status in economic and cultural global systems as it determines the range of the circulation of texts and, therefore, their span of reception. It also plays a relevant role in nation branding and cultural diplomacy, which are directly addressed to encouraging trade in foreign countries. The capitalistic forces of neoliberal globalization not only benefit from such governmental encouragement of trade, but determine to a greater degree the type of texts to undergo the economic and cultural transactions that translation involves. It is my aim in this chapter to scrutinize the role played by the translation of South Asian Canadian narratives in Spain in relation to these two major forces - the Canadian state's cultural diplomacy and cultural industries - their common interests regarding translation, and their points of friction. I propose to measure the success or failure of their enterprise by looking at the reception of these narratives in Spain in order to evaluate how "Canadian" or how "Asian" they are perceived to be by their Spanish audience. How do they contribute to the nation branding of Canada as a multicultural country, and to what extent do they participate in or resist the global phenomenon of Indo-chic?

\section{Translation in Cultural Diplomacy}

Translation Studies have provided a good number of theories and reflections on the role of this activity throughout history. However, it has been only recently that translation has started to be analyzed as a relevant tool in public diplomacy, more specifically, as a form of cultural diplomacy. In Canada, the works of Luise von Flotow (2007a, 2007b, 2008) on the translation of Canadian literature into German have been groundbreaking in this area.

Public diplomacy "is the work of governments to initiate dialogue with foreign publics in order to gain favorable opinion. If successful, public diplomacy aims to influence the policy of the target nation to the advantage of the nation installing the public diplomacy program. [...] Public diplomacy is pursued through numerous channels, primarily, international broadcasting and educational and 
cultural exchange programs (Maxwell, 2007). It differs from "classic diplomacy" in that the target is not another state's government and diplomats, but a wider audience that constitutes the "public". Among the many forms of public diplomacy, most specialists argue that cultural diplomacy is the most important, to the point that the Report of the Advisory Committee on Cultural Diplomacy issued from the United States Department of State in September 2005 (in the midst of the war in Iraq and Afghanistan)68 is titled "Cultural Diplomacy: The Linchpin of Public Diplomacy." According to American Ambassador Cynthia P. Schneider (2006), "[p]ublic diplomacy consists of all a nation does to explain itself to the world, and cultural diplomacy - the use of creative expression and exchanges of ideas, information, and people to increase mutual understanding - supplies much of its content." The fundamental idea is that culture can be used to affect foreign public opinion and garner support for a nation's foreign policies - including military interventions, as the quoted Report from the United States evidences -, and therefore "cultural diplomacy remains a valuable tool of diplomacy and is likely to become more important to governments, particularly to their public diplomacy and as a contributor to soft power, because of cultural diplomacy's promulgation of a distinctive national identity, the increasing importance of a cultural aspect in economic interests, and the intrinsic appeal of culture to globalized populations (Mark, 2008).

In Canada the goals of cultural diplomacy are targeted to opening and consolidating new and old markets for international trade and, at the same time, at protecting domestic (cultural) industries from the absorbing powers of globalization. As Simon Mark (2008) indicates, "[f]or some states, cultural diplomacy plays a role in the protection of cultural sovereignty. Canadian cultural diplomacy supports the international activities of domestic cultural industries and has sought to maintain the right to provide this support within the multilateral free trade framework." The main reasons for the promotion of Canadian culture abroad, he points out, are the direct economic benefits in the cultural industry (jobs and assets) and the visibility of Canada on the international scene, because "a country that does not project a clearly defined image of what

68 This contextualization is relevant, as the document highlights the role of cultural diplomacy at times of war, opening with this most telling paragraph: "Cultural diplomacy is the linchpin of public diplomacy; for it is in cultural activities that a nation's idea of itself is best represented. And cultural diplomacy can enhance our national security in subtle, wideranging, and sustainable ways. Indeed history may record that America's cultural riches played no less a role than military action in shaping our international leadership, including the war on terror. For the values embedded in our artistic and intellectual traditions form a bulwark against the forces of darkness" (Report of the Advisory Committee, 2005). Most experts mark 9/11 as the turning point in the prioritization of public diplomacy (Potter, 2010). 
it is and what it represents, is doomed to anonymity on the international scene (FAITC, 2010). While the second of these reasons - championed in Canada most notably by John Ralston Saul - can be understood as more politically related to the state, the first is clearly one that will benefit primarily the capitalistic interests of private companies, and not exclusively social wealth. Cultural diplomacy is more and more important in the current neoliberal moment as a governmental policy that tries to protect national interests in a transnational context, "one of a number of tools in the battle to protect their national identity from the impact of globalization (Mark, 2008).

The capital of culture, rephrasing Bourdieu's terms, is no better exposed than in its value as diplomatic instrument that attempts to "captur[e] global mind space" (Potter, 2010) in the global economy: "Canadian artists, by telling the world about Canada as only they could, influenced the way people abroad saw Canada when it came 'to invest, immigrate, import goods, travel or pursue post-secondary education.' Arts and culture could 'open international doors.' Culture was also very important to the Canadian economy" (Mark, 2008). This importance is made explicit also by Evan Potter (2010) when he explains the strategic value of diverse federal programs: "The purpose of the grants is not to subsidize Canadian culture per se; rather, it is to select specific cultural activities that will reinforce foreign policy objectives. This point is frequently misunderstood. [...] Culture is not only an essential means of projecting Canadian values and messages; it is also a multi-billion dollar business which supports some 50,000 Canadian jobs from exports alone." As the Canadian Heritage website proudly synthesizes, "Canada's innovative arts and cultural products and services help to express our diversity, values and identity. They are a vibrant element of Canada's economy- worth almost $\$ 5$ billion per year in exports of products and services."

The tasks of Canadian cultural diplomacy are carried out by three main agencies that at times cooperate and at other times compete fiercely for public funding: DFAIT (Department of Foreign Affairs and International Trade), Canadian Heritage, and Canada Council for the Arts (Compendium 2008, online). ${ }^{69}$ They all have a long history of promoting the Canadian cultural sector and its successes around the world as part of its efforts to advance Canadian foreign policy objectives, which include projects in literature and publishing: author travel, international translations, and launch tours for translated books in partnership with the Canadian Missions at the different countries where Canadian culture is exported.

69 Despite the recognition of its crucial importance by the Canadian governements, "there has been a dislocation between the commitment given to cultural diplomacy as suggested by the third pillar, and actual funding for federal cultural diplomacy. The money has not matched the rhetoric" (Mark 2008). 
Literary translation is, therefore, one of the tools of cultural diplomacy that has been listed among the prioritized activities, as this recommendation of the Advisory Committee on Cultural Diplomacy (2005) to the Secretary of the State of the US reveals: "To set aside funds for translation projects, into and out of English, of the most important literary, intellectual, philosophical, political, and spiritual works from this and other countries." In Canada, literary translation is also funded by the federal government in order to achieve its "foreign policy objectives," as mentioned above. As a crucial element of intercultural communication, translation is an influential agent in the evolution of any literary system and in the construction both of a national canon and of a global one. The promotion of Canadian writers abroad -including here the translation of their works - has been one of the key lines of work in cultural diplomacy since the 90s: "Canadian writers in English used to be 'overshadowed by more famous writers from Britain and the US,' but now themselves 'cast a long shadow.' Canada's culture was as good as any in the world, was the theme, and Canadians could rightfully be proud of this" (Mark, 2008). However, as a professional business itself, translation has proven a telling barometer of the forces of multinational corporations and of the hegemonic status of the English language in the world.

In the complex entanglement of hundreds of literary imprints that belong to merely two or three gigantic corporations, publishers "operate in terms of the modalities of multinationals" (Ponzanesi, 2006), and most often sell the rights for translation of the authors they "own" to their sister branches in other countries and languages. ${ }^{70}$ The demands of the audiences/consumers-attended and nurtured by professionals in marketing whose job includes, among other tasks,that of creating trends - will determine to a much greater extent the kind of texts to be translated in a given cultural market. Are the interests of Canadian foreign policy and the interests of global foreign audiences different? Not really. Since foreign policy attempts to defend the interests of Canadian cultural industries, it is not surprising to find that Canadian public programs have been helping those publishers who were already successful in the market. ${ }^{71}$

70 Random House, Penguin Putnam and Harper Collins are the three major publishing conglomerates of literary publishers in the Anglophone world. The three have overcome the restrictive federal measures to protect Canadian cultural sovereignty by creating their respective Canadian branches, Random Canada, Penguin Group Canada and Harper Collins Canada. Random House owns 25\% of the shares of McClelland and Stewart. They are only a small part of much bigger corporations that control hundreds of publishing imprints in other countries and distribution channels.

71 From the list of South Asian Canadian writers published in Spain, the following have received financial aid from the International Translation Programme of the Canada Council: The English Patient, Handwriting and Anil's Ghost and by Michael Ondaatje, Family Matters by Rohinton Mistry, The In-Between World of Vikram Lall by M.G. Vassanji and Neil Bissoondath's The Soul of All Great Designs. 
The International Translation Grants program of the Canada Council for the Arts subsidizes the publication of Canadian works in foreign languages abroad, covering half the honoraria for the translator, though never the printing, editing and distribution of the translated text. The program specifically states that "[p] riority will be given to books that have been short-listed for or have won literary awards (for example, Governor General's Literary Awards [...] and Canada-Japan Literary Awards)" (Canada Council website), a condition that can work to favor affluent mainstream publishers over small ones and which capitalizes on the cultural value already obtained by a book (Kim, 2008). According to Christine Kim (2008), despite the symbolic value which prestigious prizes bring to small publishers, the economic burden they carry in terms of publicity and reprinting costs is often too high to be confronted successfully.

These aspects will be further considered later in relation to the South Asian Canadian texts that have been translated into Spanish. As Luise von Flotow (2007) has observed, "[l]iterature in translation, in other words, has been found to rarely circulate innocently or by chance. It is circulated - by certain powers, at certain times, for specific purposes ... diplomatic and mercantile." I suggest that the foreign policy objectives that determine the selection of cultural activities to be promoted by the Canadian government are, in fact, coincident with the kind of cultural products that bring more profit to mainstream publishers in the global market.

\section{The Circulation of Canadian Multicultural Literature}

One of the main goals of public diplomacy is that of nation branding, to which cultural diplomacy significantly contributes. Several critics point out the "gap between how Canadians viewed themselves and how others perceived them," and policy designers were appalled to learn that "[a]ccording to a review of Canada's international brand undertaken in 2000, contemporary elements - dynamism, innovation, technology, tolerance, competitiveness and multiculturalism - were conspicuously absent" (Potter, 2010) Branding Canada was then identified as a major task to be performed by Canadian diplomacy. All efforts have been consequently directed to this goal, which brings a double benefit to the country, since a positive international projection has a strong impact on the domestic citizens' self esteem, a value foregrounded by Jozef Bátora (2005): "Although public diplomacy in the most commonly used meaning of the term seeks to engage actors abroad (that is, outside the state), an essential pre-condition for a successful public diplomacy is the attractiveness of ideas and values that a state represents to the actors inside the state. The state, in other words, needs to be 
attractive not only to foreigners, but also (and perhaps more importantly) to the domestic constituency, who will then gladly associate their actions abroad with their state and hence promote its soft power ...In this way, the state's ability to capture the mind space of foreign audiences is enhanced."

The promotion of Canadian culture abroad "provided a feel good factor that served to make Canadians proud of their country, enhance social cohesion (partly through the presentation abroad of aspects of Canada's multiculturalism), and refashion Canada's national identity (Mark, 2008). This aspect of "foreign" policy is not a collateral one; when considering the kind of texts from Canada that get widely distributed abroad, one may get the idea that the image of harmonious multiculturalism promoted by its literature is intended to reinforce dominant liberal definitions of the Canadian nation for domestic consumption rather than to convince foreign audiences of the multicultural nature of the country. Numerous studies on Canadian public diplomacy point out that multiculturalism is the most valued characteristic of Canadian society (Stairs, 2003). ${ }^{72}$ The promotion of Canada as a cosmopolitan and multicultural society has been the responsibility of Canadian Heritage (Bátora, 2005). These promoted qualities, "Cosmopolitan" and "multicultural," are key terms in my consideration of the selection of racialized Anglophone authors circulated in translation in Spain and the main point of confluence of the Canadian state's and private publishers' interests.

On the international scene, as Emily Apter (2001) explains, "[t]here are specialized niche markets within the 'global' that contribute to fads and fashions (to wit, the current popularity of Indian English-language novelists and Irish playwrights), sorting writers into subcategories such as 'international'... 'postcolonial'... and 'multicultural,' 'native,' or 'minority.' [... ] These labels, though they can help launch or spotlight world-class writers - pulling them out of ethnic area studies ghettos on the bookstore shelves - also cling like barnacles to their reception and afford constrictive stereotypes of identity." Canadian literature has contributed notably to the creation of such a global taste for the ethnic Other. In Canada, where "visible minorities" have a long history of struggle for, precisely, visibility, the rise of Multiculturalism as an official policy from the 1970 s onwards gave place to a "Multicultural Literature" that has effectively been instrumentalized in Canadian public diplomacy (von Flotow, 2007a) for nation branding, as a convenient representation of

72 Since the issuing of the Review of 1995 "Canada in the World", where it was stated that "[o]nly Canadian culture can express the uniqueness of our country, which is bilingual, multicultural, and deeply influenced by its Aboriginal roots, the North, the oceans, and its own vastness (FAITC, 2010), more recent programs have focused on the change from a predominantly pastoral view of Canada as "a land of mountains, snow and maple trees [...] to one of an innovative, cosmopolitan and multicultural society" (Mark, 2008). 
Canada state on the international stage. ${ }^{73}$ Prominent "ethnic" authors like Michael Ondaatje or Rohinton Mistry figure in the new Canadian canon that is taught, reviewed and promoted internationally, both in English and in translation (also in Spain). Although the success of these South Asian writers - conveniently indexed in our literary systems as "diasporic," "multicultural," or "ethnic"- is highly indebted to the work by diverse activist groups that demanded public space and visibility for racialized artists, their commercialization in the cultural market has exposed a renewed Orientalist desire that has led numerous critics to affirm that "[i]mmigrant writers have become a commodity" (Ponzanesi, 2006). The commodification of multicultural/ethnic writing in Canada and its negative implications for anti-racist activism have been extensively studied. The ongoing internal debates in the last decades over appropriation, racism and cooptation have critiqued that idyllic image of Canada, one that Smaro Kamboureli (2007) has described as the "fetishization of its multicultural makeup." These protests could be understood as an important impulse behind the Canadian government's urge to promote the multicultural brand in the present decade, while the preference for South Asian narratives - besides participating in the wider phenomenon of the Indian boom to considered below - has been associated by Donald Goellnich (quoted in Kim, 2008) with domestic political issues, when he suggests that their choice to "focus in their fiction on the past in a distant place that still haunts them, another place, not here, rather than writing novels about racism and discrimination in Canada may also help to explain why it has been easier for their works to get published by mainstream publishing houses." 74

\section{Global Indo-chic and its Reception in Spain}

In Spain, Canadian titles available in translation from racialized writers are scarce, and most of them happen to be award recipients of South Asian origin, confirming Graham Huggan's theories in The Postcolonial Exotic: Marketing the

73 Because narrative is, undoubtedly, the best selling literary mode and English is the hegemonic language of globalization, I am limiting my study here to the fiction by South Asian Canadian writers in that language.

74 In her comparative study of Shani Mooto's Cereus Blooms at Night and Larissa Lai's When Fox Is a Thousand Christine Kim suggests that the limited success of the second as compared to the first novel may be due to the "troublesome position [it] takes up within dominant ideas of the nation, as the novel demonstrates the limits of official multiculturalism" (Kim, "Troubling the Mosaic," 163). The first, on the other hand, has been read as a "postcolonial" text that does not criticize this most cherished quality of the Canadian nation(s) and this would explain, for Kim, its international projection. 
Margins. To my knowledge, there is no translation into peninsular Spanish of texts by Black Canadians written in English, only two by a Native Canadian (Ruby Slipperjack's Honrar al sol (2007) and Joseph Boyden's Tres días de camino (2010). East Asian Canadian fiction is limited to only four titles: Lydia Kwa's Un lugar llamado ausencia (2002 by Seix Barral; 2005, in a collectible series titled "Biblioteca oriental" ("Oriental Library," by Planeta), Denise Chong's La niña de la foto (Salvat, 2002), Nancy Lee's Chicas muertas (Circe, 2007) and Madeleine Thien's Certeza (Alfaguara, 2007), significantly, all by women writers.

The list of titles by South Asian Canadian authors in peninsular Spanish (Castilian) is limited to seven writers, Michael Ondaatje being the one who has the highest number of titles in translation. The list of Ondaatje's Works which have been published in Spain includes: The English Patient/El paciente inglés (1995, 1997, 1998, 2003, 2004, 2008); 75 In the Skin of a Lion/En una piel de león (Tusquets, 1989; Destino, 1999; Punto de Lectura, 2009); Running in the Family/Cosas de familia (Destino, 1998); Coming Through Slaughter/El blues de Buddy Bolden (Destino, 1999); Handwriting/Escrito a mano (Hiperión,2000); Anil's Ghost / El fantasma de Anil (Destino, 2001, 2002), Divisadero (Alfaguara, 2008); Las obras completas de Billy el Niño (Punto de Lectura, 2008); Shani Mootoo's Cereus Blooms at Night/El cereus florece de noche (Debate, 1999); Rohinton Mistry's A Fine Balancel Un perfecto equilibrio (Mondadori and Círculo de Lectores, 1999; Nuevas ediciones de Bolsillo, 2006), Such a Long Journey/ Un viaje tan largo (1999), Family Matters/Asuntos de familia (Mondadori, 2003; Nuevas Ediciones de Bolsillo 2004), Tales from Firozsha Baag/Cuentos de Firozsha Baag (Mondadori, 2007); Anita Rau Badami's The Hero's Walk/El paseo del héroe (Ediciones del Bronce 2001); Shyam Selvadurai's Cinnamon Gardens/ Jardines de canela (Salamandra 2001, 2005); Shauna Singh Baldwin's What the Body Remembers/Lo que el cuerpo recuerda (Anagrama 2002); M.G. Vassanji's The In-Between World of Vikram Lall/El mundo incierto de Vikram Lall (Salamandra, 2006,2008); Neil Bissoondath's The Soul of All Great Designs/Falsas identidades (Maeva, 2010).

Some of these works were also simultaneously translated into Catalan: Ondaatje's El fantasma d'Anil (Destino, 2001); Badami's El camí de l'heroi (Columna, 2001); Baldwin's El que recorda el cos (2002); Mistry's Un equilibri perfecte (Edicions 62, 2002), Afers de família (RBA-La Magrana, 2003, 2005)

75 The English Patient has been distributed in Spain by a variety of publishers and in a variety of formats. Its first edition, reprinted several times, appeared in 1995, in the emblematic Spanish imprint Plaza y Janés, bought by Berstelmann in 1984 and later assimilated by Random House Mondadori in 2004. It has also been published by Círculo de Lectores (1998), Mediasat Group (2003), and RBA Collectibles (2004). The rights of Ondaatje's novels are currently owned by Punto de Lectura, an imprint of Santillana Ediciones Generales which is part of the the PRISA group. 
and Vassanji's La patria aliena de V. Lall (RBA-La Magrana, 2006). None of them are available in Basque nor in Galician, ${ }^{76}$ although there is an interesting exception in this last peripheral literary system: the translation of Rachna Mara's Of Customs and Excise (1991) as Entre o costume e a ruptura (1998), the result of the personal interest of writer and translator María Reimóndez, who had studied the text in my classes on Canadian Literature at the University of Vigo. Her advantageous position as an award-winning author and prized literary translator in the Galician publishing industry enable her to influence her publisher's decisions on translation. Although this is not the most frequent procedure, since "[c]urrent copyright law ensures that translation projects will be driven by publishers, not by translators (Venuti, 1998) publishers may be receptive to titles that come with the extra symbolic value attributed by the prestigious author/academic who signs the translation (and they will in turn publicize this collaboration). These highly reputed translators thus constitute one more agent of legitimation that confer prestige and merit among the many "relatively neglected agents of literature-making including editors and publishing houses; literary agents and their firms; film producers and their backers; booksellers and book clubs; university professors and the academy; prizes and their judges, administrators and sponsors; book reviewers, fiction editors, and the journals that employ them; and, very importantly, other authors" (Ponzanesi, 2006).

This group of South Asian Canadian writers have been especially successful, publishing with mainstream houses (all of them have published some title with the powerful Random House), ${ }^{77}$ receiving multiple awards and distinctions including the Booker Prize, the Giller Prize, the Commonwealth Writers Prize or the Lambda Literary Award. They have achieved international recognition, reaching further into foreign publishing markets (in English and in translation) than any other new racialized literary figures from Canada. ${ }^{78}$ The interest of Spanish publishers, critics and lay readers in South Asian Canadian literature in English must be understood in the context of the so-called "Indian boom" in international cultural markets that has a wider resonance affecting all sorts

76 Contrary to the higher status of the Catalan literary system (many mainstream publishers are settled in Barcelona), publishers in the minoritarian literary systems of the Basque and Galician languages have difficulties getting the rights for translation of titles published in the dominant language, Castilian; besides, the competition with a language of higher social prestige that is understood by their audiences is an unequal one.

77 However, in Spain only Rohinton Mistry has been published by Random House Mondadori.

78 It is relevant to take into account the role of these prizes and awards for the translation of these titles: of the books by Shani Mootoo, Anita Rau Badami, Shauna Singh Baldwin and V.G. Vassanji, only their most awarded ones have been translated into Spanish and Catalan. 
of culture, high and low (food, clothes, body decoration, film and music, for instance), ${ }^{79}$ in what has been called Indofrenzy and Indo-chic.

The Rushdie affair and Arundhati Roy's Booker Prize (1997) were two main catalysts at the turn of the century for the contemporary success of Indian fiction in English. Their frequent appearances in the media served to promote Indian fiction in English all over the world, and most especially in the West, a success confirmed by V.S. Naipaul's Nobel Prize in 2001, the Man Booker Prizes awarded to Kiran Desai in 2006 and to Aravind Adiga in 2008, and the Slumdog Millionaire (Boyle's film adaptation of Vikas Swarup's novel Q\&A) global phenomenon, together with an important number of other South Asian novels translated into diverse languages in recent years and the precedent of Michael Ondaatje's Booker Prize (1992) and Anthony Minghella's film adaptation of The English Patient (1996). As can be inferred from the number of times that The English Patient has been reprinted in Spain, it can be interpreted as a clear case of how the book industry has located and exploited a foreign text which already possessed the potential for a large readership because it had been adapted to another form of mass culture, in this case a Hollywood award-winning film (Venuti 1998).

In Spain, while Canadian Studies have a much longer tradition in academia (for instance, the Spanish Association for Canadian Studies, AEEC, was founded in 1988 and became a member of the International Council for Canadian Studies in 1990), the recent interest in Indian culture ${ }^{80}$ is acquiring all the stamina that Canadian Studies seem to be losing (due mostly to the severe cuts in programmes assisting national associations: Spain's was withdrawn in 2008 and the entire Understanding Canada scheme (except The Canadian Leadership and the Canada-US Fullbright Programmes) programme has been terminated in May 2012.

In Spanish newspapers and magazines, South Asian Canadian writers have been promoted and read mostly as "Indian" or Sri Lankan authors respectively, ${ }^{81}$ and their added value as migrant authors is foregrounded with persistent references to the many displacements in their lives, where sentences like "born in Sri Lanka/India/Kenya, educated in the United States/Great Britain, now lives

79 Deepa Mehta's films have been received warmly in Spain.

$\mathbf{8 0}$ The Spanish Association for Interdisciplinary India Studies (AEEII) was created in 2007. Interestingly enough, the first conference of this association was held in the summer of 2009 in Córdoba around the topic "India in Canada, Canada in India: Managing Diversity", with the participation of M.G. Vassanji, Padma Viswanathan and Nurjehan Aziz as plenary speakers.

$\mathbf{8 1}$ Michael Ondaatje has been mistakenly described as a "Canadian writer of Dutch origin raised in India" (Giménez; my translation). Vassanji is presented as an Indian author born in Nairobi. 
in Canada" are common stock (though more often than not Canada is not even mentioned as their place of residency). Michael Ondaatje has been mistakenly described as a "Canadian writer of Dutch origin raised in India (Giménez, 2004). ${ }^{82}$ Vassanji is usually presented as an Indian author born in Nairobi. References to their Canadian "nationality" are, for the most part, nonexistent. Only after Margaret Atwood's Prince of Asturias Prize in 2008 has Ondaatje become "Canadian" in Spain, for the promotional tour of his novel Divisadero (published in Spain that same year), profiting thus from the "Atwood effect" in the Spanish media. ${ }^{83}$ Ondaatje's international (and, by inclusion, Spanish) celebration elicits a tension: that between the bolstering of Ondaatje's position as "a Canadian Ambassador abroad" - contributing to Canada's cultural legitimacy- and the unsettling of the same position through the international emphasis on his Sri Lankan identity which conceals his Canadianness (Roberts, 2011).

The list of awards, shortlistings and longlistings of these writers is, however, not forgotten. Their novels are systematically described in terms that emphasize their hybridity ("mestizaje" being a trendy term in Spanish when alluding to "world cultures"), and their synopses allude to displacement and dislocation, cultural clash, war and "turbulent times," colonial times, social conventions, arranged marriages, gender and sexual oppression, submission and rebellion, while in terms of style they are praised for their sensuality and lyricism. As a representative example we may consider the promotional text for Shyam Selvadurai's Jardines de Canela used by internet sellers, where all the above clichés are reproduced, together with this synthetic line: "Cinnamon Gardens is a portrait tainted by nostalgia for the placidity of colonial life suddenly shaken by convulsive political

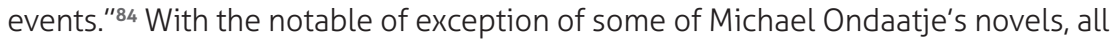
the fiction by South Asian Canadian authors translated into Spanish takes place in "exotic" lands (the Caribbean, Africa and South Asia), not in Canada (too cold and Western to be considered "exotic" by Spaniards), and this is considered an asset, as expressed in this review of Mistry's Cuentos de Firozsha Baag: "Mistry, although a resident in Canada since 1995, stands out for not having abandoned 'indi' themes in his novels. It is precisely this characteristic which gives his work a special touch. In Tales from Firozsha Baag Mistry portrays the diverse aspects of everyday life in the industrialized cities of India, where tradition and modernity go hand in hand in a completely natural way" (Javaloyes, 2007).

82 All translations from reviews and blurbs are mine.

83 While in the interviews and reviews of El paciente inglés and El fantasma de Anil his Asian origin is always mentioned, there is no allusion whatsoever to his biography and origin in the review of El Blues de Boddy Bolden by José María Guelbenzu in El País (Guelbenzu, 1999).

84 Promotional synopsis for Jardines de Canela, by Shyam Salvadurai (Google Books). 
At Spanish universities, South Asian Canadian writers are included in courses, seminars and conferences on Indian fiction in English, diasporic literature and/ or migrant literature, and they are usually inserted without further comment in the long list of famous Indo-English authors:

On the shelves in Spanish we find pioneer authors like Rabindranath Tagore (who translated himself into English from his mother tongue Bengali); two of the three narrators considered to be the fathers of the Indian novel in English, Mulk Raj Anand and R.K. Narayan (the third one, Raja Rao, has not been translated); bestsellers who started to emerge in the eighties, like Salman Rushdie, Arundhati Roy, Amitav Ghosh, Vikram Chandra, Anita Desai, Vikram Seth, Chitra Banerjee Divakaruni and Manju Kapur; other authors of international prestige like Rohinton Mistry, Manil Suri and Gita Mehta, and also some scarce texts by Anita Rau Badami, Anita Nair, Ardashir Vakil and Amit Chaudhuri (Sales, 2005).

This is the case also with Spanish publishers themselves, judging from the testimony of Jorge Herralde (founder and director of Anagrama, which published Singh Baldwin's novel What the Body Remembers in 2002) when asked in an interview about his new interests: "I don't have any editorial patriotisms, nor do I discover anything new: 'discoverer' is an imposing word. I do intend to publish the most valuable of what emerges in diverse contexts. Perhaps the most splendorous literature of the recent years has been Indian English Literature, with Arundhati Roy, Vikram Seth, Salman Rushdie, Gita Mehta and Amitav Ghosh, well known by Spanish readers. My next bets in this area are Ardashir Vakil, Pankaj Mishra and Shauna Singh Baldwin (Berasátegui, 2000).

Only those academics with a solid background in Canadian Literature speak of these writers as Canadian authors or specifically as South Asian Canadian, as most of the papers presented at the first AEEI conference evidenced. ${ }^{85}$ Due to the fact that most of the Canadianists in Spain have been supported in our research by the funding agencies and programs of DFAIT and of the International Council for Canadian Studies, we can consider the promotion in our courses of these South Asian authors as Canadian proof of the success of Canadian foreign policies on cultural diplomacy. While sponsoring their publication abroad through translation and tour programs does not seem to have had much effect on the Spanish readers and reviewers' perception of their Canadianness, studying them in courses on Canadian culture does help sustain that notion of Canadian multiculturalism that the government

85 Juan Ignacio Oliva dedicates one chapter of his study Historia, clase, género y raza en la literatura angloindia en la diáspora to South Asian Canadian women poets. 
is so interested in portraying. For the publishers, nevertheless, the economic benefit resides, in this decade, on the exotic appeal of their "Oriental" background. ${ }^{86}$ As von Flotow has indicated, "the translating culture is as much, if not more, involved in the selection of the foreign materials it wishes to have circulated and read as any neo-colonialist force providing the funds to make this possible (von Flotow, 2007a), and it is quite clear that right now the Spanish public demands "Indian" fiction. But, as Sandra Ponzanesi (2006) reminds us, it is the essential nature of any (cultural) market to prey on novelty, and "what this year is Indo-chic may next year be Moroccansuave and then the following year Latinfusion." Despite the success in the markets of these texts, it is too early to know which ones will resist the test of time and maintain their canonical status. Rachna Mara's and Shani Mootoo's translated works are no longer available in Spanish bookstores. To this date, no other work by Baldwin or Badami has been translated, although both of them have published other novels and stories later. Popular surveys like the BBC's Big Read of 2003 show that despite the undeniable support of literary prizes to turn a novel into a bestseller, awards neither grant durable favor among readers, nor guarantee sure access to the literary canon: on the list of best books chosen by participants in the BBC Big Read survey, Rushdie's Booker of Bookers, Midnight's Children came in position 100, while Mistry's A Fine Balance came in 196 (Ponzanesi, 2006), and "even Michael Ondaatje's The English Patient is missing, the fanfare around the Booker in (1992) [sic] and the film (1996) being forgotten" (Ponzanesi, 2006). In Spain, Ondaatje and Mistry have had several reprintings of their works, and seem, so far, to do well among critics and readers. The impulse given by "the Atwood effect" in 2008 might be behind the publication of new and old titles by Ondaatje, Mistry and Vassanji that year and during the following one. The absence of more books by South Asian women authors is certainly surprising at a time when "Indian" novels by women continue to be translated in significant numbers every year. Their ephemeral success seems to confirm the hypothesis of the "supposed tokenism for shortlisted black, female or diasporic authors" (Ponzanesi, 2006), who are translated at the moment of their widest international attention in the media but are no longer supported after that. Why are their new titles not being translated into Spanish? I leave the question open to their publishers.

86 While in the English language there is a clear distinction between the terms "East" (as a geographical reference) and "Orient" (as a cultural construction), in Spanish the word "oriente" is used in both senses. 


\section{Conclusions}

It has been my aim here to examine the role that South Asian Canadian fiction in translation plays as a form of cultural diplomacy that contributes to nation branding - reinforcing on the international scene the image of Canada as a multicultural and advanced nation that provides self-confidence to Canadians themselves -, and attempts to pacify protests by antiracist cultural and political activism on the domestic scene, since as Ken Lum has remarked, "[multicultural] diversity was designed to be the basis of the cultural pillar of Canada's foreign and domestic policy" (quoted in Maxwell, 2007).

The emphasis on multiculturalism as the crucial Canadian value to be branded in cultural diplomacy has helped to project globally a selection of multicultural authors of whom the majority happen to be of South Asian origin. From the perspective of Canadian cultural diplomacy, the narratives of these authors may seem safer and less politically compromising for their (neo)liberal interests. Besides, they are a perfect point of confluence with the economic interests of powerful Canadian cultural industries that benefit from the sales of their authors within the global Indo-chic boom.

The small number of South Asian Canadian authors translated in Spain is still much higher than the list of authors from any other racialized community from Canada. All these authors publish (or have published in the past) in Canada with imprints of Random House, the most powerful publishing group in the literary realm. Economic interests of private corporations and the political interests of Canadian public diplomacy coincide, then, in their instrumentalization of South Asian Canadian fiction. However, the political aim of cultural diplomacy at risk in Spain by the marketing and circulation of these narratives as "Asian" texts, more specifically as "Indian" texts (regardless of the ethnic origin of their authors or their nationality). Judging from the promotional synopses and biodata offered in interviews and reviews (both academic and in newspapers), these books are read as "Indian" books, not as Canadian ones, and only Ondaatje seems to have been recently labelled as a Canadian author. Because these stories are set far from Canada, Spanish readers fail to see them as the products of Canadian multiculturalism, as the federal programs would like them to be appreciated. This proves true von Flotow's observation (2007) that "the process [of cultural diplomacy] and its outcome depends as much if not more on the participation and choices of the receiving culture." The translation of a greater diversity of racialized authors from Canada in Spain would help greatly to offer a more accurate view of the cultural capital of Canadian writing. In order to achieve the objectives of cultural diplomacy to brand Canada as a multicultural country on the international sphere, greater efforts must be made by governmental funding agencies to support the translation and international promotion 
of Black Canadian, Native Canadian, Inuit and other Asian and minority writers of diverse ethnic backgrounds into Spanish, and then export them to other Spanish-language markets (see Martínez-Zalce, 2001). Relying on the economic success of some token ethnicities in a global market driven by monetary awards is a poor contribution to a true implementation of Multiculturalism and a tactic that, at least among Spanish readers, fails in its main objective. The wealth of racialized writing from Canada is too great to be so reductively delivered abroad. 